\title{
「国際交流に関する情報・プロジェクト」報告
}

国際交流に関するプロジェクト助成を受けた 2 名の学会員から報告書が提出されました．以下に要約 を揭載いたします．報告書の全文は学会ホームページに掲載される予定ですのでご参照ください．国際 交流委員会では，学会員の国際交流に資するために，今回のような学会大会に関する情報だけではなく 様々な国際交流に関する情報を広く募集しています．募集要項をご覧になり奮ってご応募ください.

\section{Dance from Japan and Kenya - Utilizing the Technology of Motion Capture -}

立命館大学産業社会学部 遠藤保子

立命館大学 COE 推進機構ポスドク研究員 小島一成

2004 年 7 月 25日 $14: 00 \sim 15: 30$ 於：Clarion Music Center

日本とアフリカにおける舞踊の比較検討を行いつつ, 舞踊と社会や文化の関係をテーマに講演した. 事例としては，2003年度モーションキャプチャシステムを用いて収録分析した鹿児島県における6つの 疱瘡踊り（研究代表者：高橋京子）とケニアにおける6つの代表的な伝統的舞踊分析結果を中心に, 筆 者によるモーションキャプチャのデモンストレーションを交えて行った。講演終了後の質疑応答には, さまざまな感想や意見が寄せられた：日本の疮瘡踊りに見られる祈願構造が括しろい.アフリカの舞 踊特性がより鮮明に理解できた。モーションキャプチャが，舞踊の分野にも応用できることを知って参 考になった。デモンストレーションを通して，舞踊をさまざまな角度から再現することができ，動作の 特徴が肉眼でみるよりも鮮明に理解できるのは, 興味深い。モーションキャプチャを利用するには, 高 額な設備が必要であるため，アメリカでも研究機関が協力して利用できるように検討すべきではないの か. 今回の講演は，まったく新しい方法でアプローチしたのでユニークだと思う，など.

モーションキャプチャは，現時点ではある限られた分野でしか活用されていないし，モーションキャ プチャの会社があるアメリカでさえ, それを駆使した舞踊研究は, 今のところほとんど行われていない。

本講演は, 日本の先進的でユニークな舞踊研究を発表したという意味において有意義だったと思って いる.

\section{第22 回国際スポーツバイオメカニクスシンポジウムに参加して}

名古屋大学大学院 佐野真也

2004 年 8 月 9 日〜 12 日にカナダ，オタワのオタワ大学において開催されたXXIInd International Symposium on Biomechanics in Sports (ISBS) に参加した。学会は Geoffrey Dyson Memorial Lecture, キーノートレクチャー6題, 口頭発表 104 題, ポスター発表 70 題から構成されていた。キーノ ートレクチャーのテーマは主に，スポーツのテクニックやパフォーマンスに関するもの，スポーツの障 害（あるいは傷害）に関するもの，の2つに大別できた．このことは，スポーツバイオメカニクスの担 う役割は主に, パフォーマンスの向上に貢献すること，スポーツによる障害および傷害を予防すること， の 2 点であるということをISBSが明確に意識している，と感じさせるものであった。一般発表（口頭 およびポスター）において特に感じたことは，工夫を凝らしたスライドやポスターを作成することの重 要性である，単なるデータの羅列であったり，必要以上に長い説明であったり，スライドに工夫のみら れない発表は, 理解するのが困難であった，私自身も発表を行ったが，幸いにも発表を聴いていた参加 者には理解してもらえたようであった。また，日本人研究者の発表は，口頭においてもポスターにおい ても, 工夫され，わかりやすいものが多かったことも付記しておきたい. 今回, ISBSに参加したこと で，研究者のみならず，コーチや選手としても相当な実力を持った方と話をする機会にも恵まれた．研 
究と現場，両者の立場を知る方と話をする機会を持つのは重要なことであるように思う。全体的に振り 返ると，ISBSがその目的の一つとして揭げる，研究の場と現場とのギャップに対する橋渡し，という 部分については，まだ模索中であるという印象を受けた。それでも，バイオメカニクス的な手法で得た データを元にトレーニングを行ったり，ビデオ映像とデータを同期させて表示したりといった工夫が随 所にみられる学会であった。 